\title{
ON A NEW RHABDOCGLE COMMENSAL WITH MODIOLUS PLICATULUS
}

\author{
EDWIN LINTON \\ Professor of Biology, Washington and Jefferson College \\ FORTY-ONE FIGURES
}

During the summer of 1909 , while searching for sporocysts and rediæ in the mollusks of the Woods Hole region, at the Bureau of Fisheries Laboratory, I found an interesting turbellarian in the ribbed mussel which is not only new to this continent but which possesses some characteristics which seem to mark it as unique among the Rhabdocœlida.

The first specimen encountered was taken to be a redia, but later when it was noted that not only was the worm ciliated, but that it contained ciliated young, it was seen to be a viviparous rhabdocole. After much experimenting it was found that the worms could be collected to the best advantage by opening the shells of the mussels and shaking the animals about in a dish of sea water. They are thus washed off the gills and will be found creeping about on the bottom of the dish. Much time was spent in looking over the gills and mantles of mussels in the hope of finding some of the worms in place; none were found, however, on any part of the animal. This is not to be wondered at when the small size of the worms is considered, and further, that they are practically the same color as the gills. Indeed it happened more than once that what was thought to be one of the worms proved to be a small piece of gill or mantle which had been torn off by accident and was moving about in the water by its own ciliary action.

The species belongs to the genus Graffilla or to a closely related genus, but is quite different from any species noted by von Graff in his Monographie der Turbellarien. 


\section{DESCRIPTION OF THE SPECIES}

\section{Grafflla gemellipara sp. nov.}

Small, rarely reaching $2 \mathrm{~mm}$. in length; nearly linear, bluntly rounded at the extremities, often round-pointed at the posterior end, frequently bent a little to one side, making the outline arcuate, rather thick; ciliate throughout; color white, often tinged with yellow or greenish-yellow along the middle line; mouth small, ventral, near the anterior end; pharynx subglobose; esophagus short; intestine very difficult to distinguish in living specimens, extends along the dorsal side to the posterior end, its limits not always well-defined; eyes two, black, reniform, with a well defined "brain" behind them; genital opening very small, ventral, situated at about the anterior third. There is a pyriform seminal vesicle which communicates with the genital pore by a short duct in which lies a plug-like penis. The ovaries are two ribbon-like bodies placed laterally and beginning about the anterior fourth and extending to the middle of the body. The yolk-forming cells (vitellaria) appear to be continuous with the ovary and are widely distributed. In all the larger specimens there were numerous young in various stages of development. The fully developed young, as a rule, lie together by twos inside a thin capsular envelope. They are ciliated and very active, turning round and round within the capsule, or, after breaking through the capsule, making their way with ease through the mesenchyme of the parent. In the larger worms there are usually a number of small, irregularly coiled string-like bodies scattered throughout the body which have the appearance of being secretion products (figs. 16, 17). At first the idea that they are either of the nature of giant rhabdites or spermatheca was suggested. They appear to be collapsed embryonic capsules from which the embryos have escaped. Some specimens were collected which were immobile and contained but little beside the numerous active young. The latter are evidently not liberated until the reproductive powers of the mother are exhausted when they make their escape through the ruptured body-wall. Dimensions, in millimeters, specimen slightly flattened; length 1.54 ; breadth, maximum, 0.65 ; breadth 
at eyes 0.28; distance between eyes 0.10 ; distance of eyes from anterior end variable, but most of the time about 0.14 ; pharynx nearly circular in outline and about 0.09 in diameter; ciliated young very variable in life, on account of contraction changes; but usually 0.12 to 0.14 in length; diameter of a capsule containing a pair of young 0.11. A small specimen without young, slightly compressed, measured 0.56 in length and 0.32 in breadth, and the diameter of the pharynx was 0.04 . A large specimen, which was in a moribund condition, semi-transparent, turgid and devoid of cilia, measured 1.75 in length, 0.37 in breadth at the eyes, 0.63 at the middle, and 0.28 near the posterior end.

\section{NOTES ON THE ANATOMY OF THE SPECIES}

It is not my purpose to give histological details; indeed, my material, although consisting of numerous whole mounts and a number of series of sections, while enabling me to understand much of the anatomy, still leaves much unexplained.

Epidermis, etc.

The epidermis is ciliated, the cilia appearing in the embryos before the pigmented eye-spots are seen. The cells are irregularly cubical with large nuclei. In cases where the epidermis was seen in living specimens crushed under the cover-glass the outlines of the cells were very irregular. Four sets of muscle fibers can be distinguished in sections from material which was fixed in Flemming's chrome-osmo-acetic fluid and stained in iron hæmatoxylin. These are longitudinal, transverse, and two sets of diagonal fibers (fig. 15). There are no rhabdites, and I fail to recognize the subhypodermal glands which are said to be present in the parasitic turbellarians.

In the living worm, under favorable conditions, there may be seen a reticulum of slender strands uniting here and there into masses of similar substance, the whole resembling a plexus of fine nerve-fibers with interspersed ganglia (figs. 13, 14). No nuclei were observed in these masses. The strands are solid, and 
I take them to represent a subdermal nerve plexus. They lie in the body-wall, probably closely associated with the muscular layers. This was evident in the living and active specimens. When the worm was contracting actively and the mesenchyme was thrown into constant motion so that the various structures which were lying in it, even such stable bodies as the pharynx and eyes, were constantly shifting their position, the reticulum remained unchanged and moved only with those movements of the worm which involved the outer body wall

\section{Alimentary tract}

The mouth, although very minute, may occasionally be seen in specimens that are lying free in sea water and viewed under low magnification. When the worm, in making its characteristic movements described below, turns the head sharply to one side, a view of the ventral surface in profile is often obtained. A notch in the outline of the ventral surface indicates the position of the mouth. This position is somewhat variable on account of the extreme mobility of the body-wall. In one that was watched for some time there appeared to be a longitudinal furrow leading from near the level of the anterior border of the pharynx to the anterior end of the body. The sides of this furrow were capable of being pressed together, thus extemporizing a gullet (fig. 5). The mouth proper appeared to be near the anterior edge of the pharynx. It was variable in shape, usually ovate with the larger end in front; sometimes it was circular. The furrow and the mouth are, of course, ciliated, as is the whole surface of the body.

The pharynx is near the anterior end and is subglobular. In the living worm it was seen performing swallowing movements, and in one case where the pharynx had been entirely separated from the body in a crushed specimen it continued to contract convulsively for some minutes.

The esophagus is short, scarcely as long as the pharynx. In a horizontal section measuring $1 \mathrm{~mm}$. in length, the pharynx was $0.05 \mathrm{~mm}$. from the anterior end, and measured $0.07 \mathrm{~mm}$. in diameter, and the esophagus was about $0.05 \mathrm{~mm}$. in length. The 
transition from the esophagus to the intestine is not abrupt. In the case cited it maintained about the same diameter for a distance of $0.05 \mathrm{~mm}$., then widened rapidly for about the same distance into the intestine (fig. 4).

The intestine extends to the posterior end of the body. Its position is dorsal. In life the cells that line its cavity seem to be rather loosely attached. They are usually yellowish or yellowish-green, especially in the older individuals. Rudiments of the esophagus and pharynx were noticed in young individuals that were still in the embryonic capsules. The intestine is usually rather difficult to see in the living specimens. In one instance it was plainly seen as a thin walled elongated sac extending nearly to the posterior end. It was filled with yellowish granules sus. pended in a fluid, and the contents were kept moving backward and forward by the contractions of the body The specimen being under slight pressure, some of the intestinal contents were pressed out of the mouth.

\section{Male genitalia}

I have not yet been able to make out the anatomy of the genitalia with entire satisfaction. This apparent indefiniteness of the genital organs may indeed be incident to the viviparous condition, which may, in turn, be seasonal and parallel with the production of summer eggs as has been shown to be the case with some of the Mesostomata. It is more probable, however, that the species is protandrous.

The genital pore is ventral and approximately at the anterior third or fourth. In one specimen which, flattened under the cover-glass, measured $2 \mathrm{~mm}$. in length, the genital pore was approximately $0.06 \mathrm{~mm}$. from the anterior end. In another, measuring $1 \mathrm{~mm}$., it was $0.25 \mathrm{~mm}$. from the anterior end. Sections show that the pore communicates with a subglobular or pyriform sac which contains spermatozoa. These were seen in active motion within the sperm-sac in living specimens. There is a short penis which lies like a plug in the duct leading from the 
sperm-sac to the genital pore. In living worms it was noted that the sperm-sac often lay behind the eyes on the middle line in such position that it and the eyes formed an equilateral triangle. The sac is usually pyriform. Inside dimensions of a living specimen: length 0.048 ; breadth, at dorsal end 0.051 , at ventral end 0.034 . In this case it was noted that the walls of the sac were clearly limited on the inner side, but not so clearly defined on the outer side. Its walls are rather thin, but they become thick and muscular where they merge into the penis sheath. In life the sac is actively contractile. On one occasion a curious behavior of the sperm-sac was noticed. An ovum, with two large, clear germ cells embedded in a mass of yolk, lay just behind the sac and touching it. The ovum was constricted in the middle where it was in contact with the sac and the two germ-cells had passed one to each side of the sac (figs. 37,38). At the posterior border of the sac there was a wisp of fibers as though sperm were being forced into the ovum. At the same time there was an almost rhythmical contraction of the posterior border of the sac. The ovum was also contracting somewhat rhythmically. In another specimen the sperm-sac, which was collapsed and pushed to one side, appeared to be trying to approach one of the densely granular ova which was lying adjacent to one side of the worm. This ovum had one large, clear germ-cell, and was actively contractile. The impression made on the mind by this behavior was that something of the nature of copulation was in progress (fig. 39). This singular action did not appear to be due to pressure of the cover-glass. In one specimen a cluster of spermatozoa was noticed on the median line a short distance behind the sperm-sac. The genital pore lay between the sac and the cluster of sperm. Similar clusters of sperm were seen in sections in a duct which lies posterior to the sac and leads dorsad to the yolk-forming cells of the ovary (fig. 40).

The testes were not satisfactorily made out. In a series of horizontal sections, made from a specimen which had been fixed in corrosive-acetic and stained with hæmatoxylin and orange $G$, branching glands near the dorsal surface (fig. 8) were at first taken to represent the testes, but are evidently vitellaria. In a young 
specimen two small, subglobular bodies were seen a short distance back of the pharynx and laterally placed. These may be testes.

\section{Female genitalia}

The ovaries are elongated, compact masses of cells lying, for the most part, lateral and ventral to the intestine. A large part of the ovary consists of characteristic cells elongated transversely to the length of the organ, with abundant, very fine-grained cytoplasm, and large, clear nuclei with conspicuous nucleoli. These cells enlarge, gather a very large amount of yolk, ultimately become detached, and are then driven about in the mesenchyme by the movements of the worm. In horizontal section (figs. 40, 41) the two ovaries are seen to be continuous on the middle line on the ventral side of the intestines with smaller cells which are more coarsely granular than the cells of the ovary and have smaller nuclei. A duct, traced from the genital pore to the middle of this gland, seems to answer to the uterus, but spermatozoa were found in it, and, moreover, there appeared to be two ducts in the vicinity of the yolk-cells. It is possible that a series of sections of a young specimen might show that there is a duct leading from the dorsally-placed testes to the sperm-sac. I have not succeeded in demonstrating the way in which the spermatozoa reach the spermsac. It will be noticed from the foregoing account that there is some reason for thinking that the cells which are liberated from the ovary into the mesenchyme may be fertilized by sperm from the sperm-sac, which, if that be the case, would then be a sperm receptacle filled from another individual. I find nothing in my sections to warrant this conclusion, and nothing in the stained and mounted specimens except one curious case of an ovum and sperm-sac in close proximity (fig. 38)

\section{DEVELOPMENT}

Many stages of development, from the large yolk-burdened ovum with a single nucleus to the ciliated young, may be seen at the same time in the same ardult worm. Some of these forms are 
figured (figs. 1 to $4,7,20$ to 30,37 to 39,41 ). It would extend this paper beyond its intended scope to describe them in detail. Briefly the normal course of events in the development of the young seems to be as follows:

1. The egg as it is liberated from the ovary-vitellarium is char. acterized by having a relatively large amount of yolk in which there is a large, clear nucleus with a distinct nucleolus (fig. $1, h$ ). How the capsule is acquired was not made out.

2. The nucleus divides, and sooner or later there is a cleavage of the resulting mass of cells into two divisions; or, the two nuclei may separate at the completion of the first segmentation (fig. $3, f$ and $b$ ). So far as I have been able to interpret the evidence, the embryos which are enclosed in the same capsule seem to have developed from the same ovarian ovum.

3. Each division is soon seen to be made up of two kinds of cells. (a) Small and numerous, massed at one pole, which ultimately becomes the head of the young worm. There is also a narrow layer of these small cells around the periphery (b) Large, globular cells, relatively few in number. These lie in the posterior region, and continue with little change in the young worms (fig. $41, e$ and $d$ ). They are probably yolk-cells.

4. The small peripheral cells soon give rise to a ciliated epithelium. A body-wall about as thick as that of the adult appears, pigmented eye-spots are developed and the rudiment of a pharynx is seen The egg-membrane persists as a capsule in which the pair of young worms are confined long after they are capable of active movements. At first they lie parallel, with their heads and tails in corresponding positions. Later the head of the one is usually beside the tail of the other. They keep up a constant movement round and round, sometimes in the same direction, but often moving independently of each other. Usually the two young and the fluid in which they are immersed are the sole contents of the capsule; at times there may be one or more masses of yolk also included in the capsule. There seem to be individual characteristics in this respect, the course of development of the young in one adult being quite different from that in another (figs. 2 and 3). A few cases were noted where there were three em- 
bryos instead of two in the same capsule (fig. 28). So far as such cases have been studied it appears that two of the three are alike and smaller than the third, which should be the case unless the original division of the first cell or the mass of cells were threefold, an occurrence certainly not to be expected. Often a young worm is seen not accompanied by its twin. These cases, as a rule, are the result of the rupture of the embryonic capsule and the escape of the young into the maternal mesenchyme where they can wander about freely. It happens, however, that, while it is the rule that two embryos develop in each capsule, only one may at times develop. This is the interpretation which I think must be given a case where a single young worm is still enveloped in the capsular covering (fig. $1, n$ ).

The cleavage of the mass of cells into two masses is preceded by the arrangement of the large and the small cells in different ways. In some cases the small cells are at the opposite poles and the large cells in the middle in which case the division takes place through the mass of large cells (fig. 1, $r$ ). Or the large cells may be at the opposite poles and the small cells in the middle, the division then taking place through the latter (fig. $3, e$ and $f$ ). In other cases it would appear that at the first division of the germ. inal spot, the resulting cells have moved apart, each building up a morula-like mass of cells. These two masses of cells remain for a long time separated from each other by an intervening mass of yolk (fig. 22). Such cases as young worms with one or more masses of yolk in the same capsule are thus explained. Some cases were observed where there was nothing but a mass of large cells within a capsule, the yolk having been entirely absorbed (fig. 25). What is the ultimate fate of such cell masses I do not know.

While I did not contemplate the study of such minute structures as nuclear elements, some of the material was prepared with considerable care. Chromosomes are clearly defined, and a few very large centrosomes were noted. What was interpreted to be a polar body was noted in one case. This was a cell which lay inside the egg capsule at the junction between the approximated anterior ends of the embryos. 


\section{MOVEMENTS}

The behavior of these worms is highly characteristic. When placed in sea water they creep about on the bottom of the dish. They move by means of cilia, but the body in addition is in constant motion. The mesenchyme is soft and yielding and responds to every contractile movement of the body-wall. Although acttively moving, the worm does not make progress in any one direction save for a very short time. For example, it will move forward for a short distance, usually not more than its own length. It will then turn the head end sharply to one side or the other. The direction of progress being thus changed, the worm will move in the new direction again for about its own length when, in the same manner, a new direction will be taken. The result is that but little progress is made unless some factor, such as graviity or light, is added. For example, if the dish is not level the worm will be found in the course of a half-hour or so to have changed its position from one side of the dish to the other. While they do not react immediately in any marked degree toward the light, in general the adults tend to move away from it. Thus they may be found to have crept up the side of the dish and be clustered near the surface of the water in response to the action of light. In order to determine whether these worms react in any way to light the following observations were made. A number of them were left over night in a watch-glass. On the following morning they were, so far as T could see, as active as they had been on the previous day. They had all gathered at the side of the dish that was turned away from the light. The side of the dish next the window was then darkened and the opposite side illuminated. In a few minutes the worms were clustered at the darkened side of the dish. The worms do not move in a straight line away from the light, but keep up their habit of starting off in a great hurry for some place, but going only a length or two in any one direction, then turning abruptly to the right or left and thus proceeding by a series of zig-zags. The result of this peculiar method of movement in its natural habitat must be to afford the animal a constant change of position, but as a rule within a limited area. 
This would appear to be in harmony with its natural surroundings. If its instinct led it to make long excursions in a straight line the chances of its being carried away from its host would be much greater than they must be with its actual hesitating manner of progression.

The test for the reaction to light was repeated with the same general result. That is, they tend to move away from the light. This instinct, again, it would appear, is what should be expected of a worm living as a commensal within the mantle-cavity of a mussel.

The ciliated young within the embryonic capsule are very active. They are constantly swimming about, and, on account of the confined space in which a pair is obliged to move, the result of the ciliary action alone would be to drive them round and round. Beside the ciliary motion there are frequent changes of direction effected by turning the anterior end of the body to one side or the other. Indeed the characteristic habits of motion of the adult can be detected in the young before they have escaped from the capsule. When the young break through the capsular wall they wander freely in the mesenchyme. Thus they were observed in all parts of the body pushing their way industriously, but never continuing in a straight course for long. They were seen even lying between and in front of the eyes, and indeed in every part of the body, but most of the fully developed young are found in the posterior third of the body of the mother. When the fully developed young escape from the body of the mother their behavior in the sea water is essentially like that of the adults. Many free individuals were collected which were but little further advanced in development than some which were still in the embryonic capsule. On one occasion a young worm was observed pushing its way through the dense median mesenchyme. When it reached the edge of the denser portion it pushed for an instant as if it had encountered something which was resisting itsprogress. The obstruction gave way suddenly and the worm passed quickly into the thinner mesenchyme which lay along the anterior margin. It is probable that the worm had strayed into the lumen of the intestine and was seen forcing its way out through the intestinal wall. 


\section{DISTRIBUTION}

This species was found only in Modiolus plicatulus. Their geographical distribution is somewhat irregular. It was soon noticed that mussels from some localities had none, while those from other localities yielded them in considerable numbers. Even two mussel beds which were near together might differ very markedly. For example, on August $10 \mathrm{I}$ examined two lots of mussels from Ram Island on which I made the following notes:

1. From the N.W. side near an old wreck, 36 , measuring from 55 to $75 \mathrm{~mm}$. in length, most of them about $65 \mathrm{~mm}$., above low tide in a kind of sedge, shells much corroded. No parasites found.

2. From a point 50 yards south of the locality of the first lot, 34, 35 to $75 \mathrm{~mm}$., mostly about $55 \mathrm{~mm}$., above low tide, sandy mud, about 75 parasites obtained.

In general it may be said that mussels in confined coves do not have these parasites. The best localities for finding them are those which are exposed to rather free tidal currents. When they do occur in a bed of mussels they are rather more numerous in the large animals than they are in the small ones.

Advantage has been taken during the process of publication of suggestions made by my friends Drs. Coe and Patterson, both of whom have shown a lively interest in this case of apparent polyembryony.

Dr. Coe writes me that he examined a lot of ribbed mussels from Savin Rock, New Haven, on Oct. 7, 1910, and finds the Graffilla fully as common as at Woods Hole. There was, moreover, an abundance of embryos in all stages in the larger specimens. 
TABLE I

The following notes will show further the somewhat uncertain distribution of this worm.

\begin{tabular}{|c|c|c|c|c|}
\hline DATE & LOCALITY & $\begin{array}{c}\text { NUMBHR } \\
\text { OF MUSBELS }\end{array}$ & $812 \mathrm{E}$ & NO. OF PARABITEB \\
\hline July & Ram Island & 50 & $45-65$ & 14 \\
\hline July & Ram Island & $\begin{array}{l}50 \\
13\end{array}$ & 25-35 & 8 \\
\hline July & Ram Island & 225 & $30-75$ & 229 \\
\hline July & Ram Island & 49 & $45-80$ & 9 large, 6 small \\
\hline July & Sheep-pen Cove & 77 & $40-85$ & 0 \\
\hline July & North Falmouth & 100 & $35-60$ & $\mathbf{0}$ \\
\hline Ju'y & Katama Bay & 30 & large & 0 \\
\hline July $\quad 30$ & Head of Great Harbor & 86 & large & $\mathbf{0}$ \\
\hline August 4 & Robinson's Hole & 78 & $55-98$ & 0 \\
\hline August 5 & Wareham & 84 & $50-70$ & 10 \\
\hline August 7 & Ram Island & 63 & $35-68$ & 110 \\
\hline August 10 & Ram Island & 36 & $55-75$ & 0 \\
\hline August 10 & Ram Island & 24 & $35-75$ & 75 \\
\hline August 27 & Cuttyhunk & 4 & $63-110$ & 5 \\
\hline August 27 & Hadley Harbor & 79 & $45-70$ & 0 \\
\hline August 30 & Ram Island & 80 & $32-75$ & 204 \\
\hline
\end{tabular}

TABLE II

The following tabular statement shows the results of the examination of a lot of $\mathbf{2 2 5}$ mussels divided according to size:

\begin{tabular}{l|l|l}
\hline No. & BIZI & No. OF PARASIT RE AND RHMARIKS \\
\hline 25 & $60-75$ & 45, nearly all large. \\
25 & $50-58$ & 7, large and small. \\
25 & $50-58$ & 42, large and small. \\
25 & $45-50$ & 16, large and small in about equal numbers. \\
25 & $40-45$ & 22, more small than large. \\
25 & $35-40$ & 28, mostly minute. \\
25 & $32-35$ & 30, mostly minute. \\
25 & $30-32$ & 17, all minute. \\
25 & 30 & 22,2 or 3 small, others minute. \\
\hline
\end{tabular}




\section{BIBLIOGRAPHY}

The literature of the Turbellaria is very extensive. Following are a few references of especial value in the study of such forms as Grafflla:

Inering. 1880 Graffilla muricola, eine parasitische Rhabdoccle. Zeit. f. wiss. Zool., 34, 147-174, Taf. 7.

LANG. 1881 Notiz über einen neuen Parasiten der Tethys aus der Abtheilung der rhabdocœlen Turbellarien. Mitth. aus d. Zool. Sta. in Neapel, Band 2, 107-112, Taf. 7.

Von Grafr. 1882 Monographie der Turbellarien. I Rhabdocolida.

Böнмıя. 1886 Untersuchungen über rhabdocöle Turbellarien. Zeit. f. wiss. Zool., 41. 220-328, Taf. 11, 12.

Luther. 1904 Die Eumesostominen. Zeit. f. wiss. Zool., 76, 1-273, Taf. i-ix. Bibliug. 259-263.

Nicoll. 1906 Notes on Trematode parasites of the cockle (Cardium edule and mussel) (Mytilus edulis). Annals and Magazine of Natural History, series 7 , vol. xvii, p. 154, plate 4, fig. 7. A form found in the cockle (Cardium edule) and identified as a sporocyst is very near, if not identical with this species. 
EXPLANATION OF FIGURES 


\section{PLATE 1}

\section{EXPLANATION OF FIGURES}

1. Sketch of specimen, flattened and mounted in balsam; dorsal view; actual length 1.43 millimeters. $a$, pharynx; $b$, esophagus; $c$, eye; $d$, sperm sac; $e, e$, embryo consisting of a central mass of cells surrounded by a yolk; others will be found to which no index lines point; for example, there is one almost exactly in the middle of the body and another just behind the embryo to which the index of $f$ points. The latter appears to be on the point of dividing. A similar stago of development will be found in front of $r$. $f$, embryo with large cells at opposite poles and separated by yolk; another will be found on the median side of the sperm vessel, while between the latter and the anterior end of the left ovary is one which is a little farther advanced. $h$, ovum with a large germ cell enclosed in yolk; $k$, collapsed embryonic capsule; another is shown just behind $n ; l$, twin embryos enclosed in the same embryonic capsule; others are shown in various parts of the body; $m$, yolk cells; $n$, single young in capsule; $o$ left ovary; $p$, mass of cells in capsule, all the yolk is absorbed; $q$, early stage of twins enclosed in yolk; $r$, this represents a stage in development just before division into two masses of cells; $z$, young escaped from capsule and wandering about in the mesenchyme.

2. Sketch of specimen which had been killed under slight pressure over flame and was lying in sea-water. $a$, two large cells with coarsely granular yolk; $b$, twins, ciliated, but the eyes have not yet appeared. In the anterior capsule there are a few yolk granules which have not yet been absorbed. This is also the case in the capsule median to $a$. In the posterior one all the yolk has been absorbed. $c$, twins, ciliated and with eyes. There are three other pairs shown; it is to be noted that in each case some of the yolk has not been absorbed.

Actual length 1.61 millimeters.

3. Another, also in sea water; actual length 1.30 millimeters. $a$, brain; $b$, ovum with a germinal cell at each end separated by yolk; $c$, sperm sac; $d$, probably a part of the ovary distorted by pressure; $e$, embryo consisting of two masses of large cells separated by yolk and small cells. This form has originated from a condition like that represented in $b$; it is about ready to separate into a pair of twins. $f$, this shows the division completed which is faintly indicated in $e$. Another representing a similar stage is just behind $f$. $h$, a pair of twins, ciliated but eyes not yet developed; $j$, twins ciliated and with eyes. It will be noticed that all the young in this specimen have divided in such a way as to include the yolk. $k$, a granular body, probably an ovum in which the nucleus is concealed by the mass of yolk.

4. Longitudinal, horizona! section $a$, pharynx; $b$, esophagus; $c, c$, intestine; $e$, segmenting ovum similar to $f$, fig. $1 ; f$, segmenting ovum, large cells at opposite poles; $j, k, l, m$, ciliated embryos; $o$, ovary. Length 0.97 millimeter.

5. Ventral view of head showing mouth and a preoral furrow; skctched from life. 

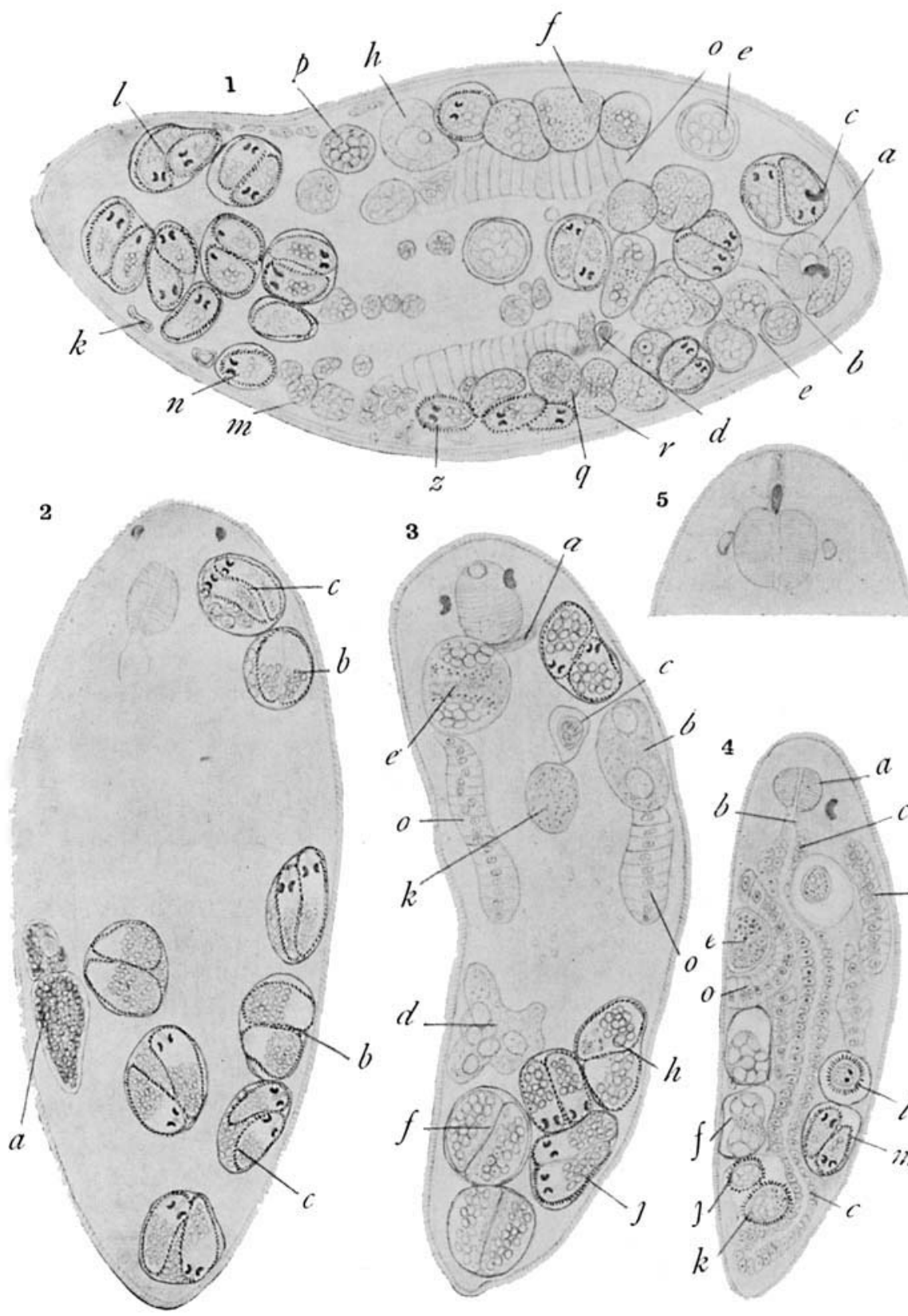

3

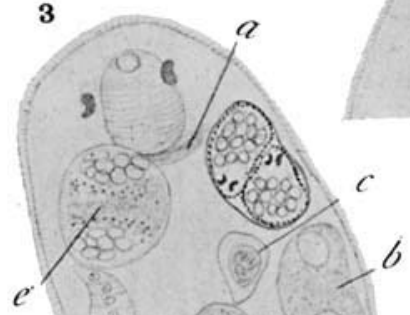

5
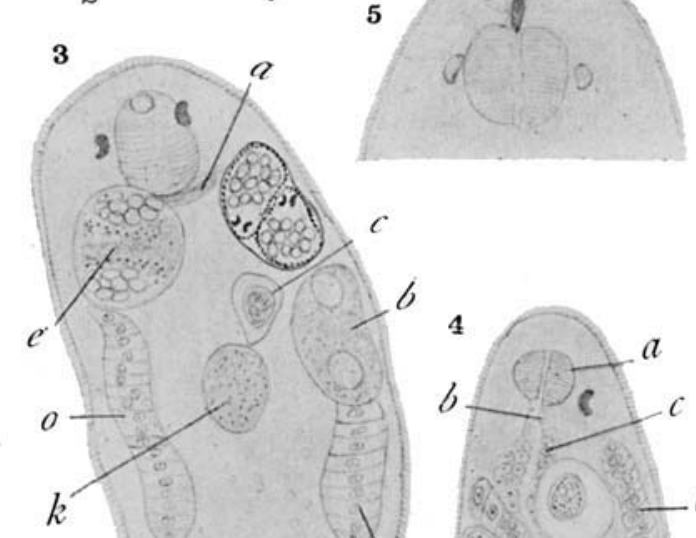

THE JOURAAL OF FXPERIMENTAL ZOÖLOGY, vOL. 0, NO. 2. 


\section{PLATE 2}

\section{EXPLANATION OF FIGURES}

6. Horizontal section showing brain; actual diameter in region of the eyes 0.17 millimeter. $a$, pharynx; $b$, brain; $c$, muscular layer; $d$, cells in intestinal wall, diagrammatic; $o$, ovary.

7. Transverse section; actual breadth 0.36 millimeter. $a$, vitellaria; $b$, intestine, diagrammatic; $c$, embryonic capsule containing ciliated twins; $d$, section of single young; $e$, probably section of ovum like that shown in fig. $1, p ; f$, mass of yolk cells; $o$, ovary. The intestine is on the dorsal side of the section.

8. Horizontal section in dorsal region; actual length 0.4 millimeter. $a$, vitelaria.

9. Epidermis separating from the body of a specimen crushed under cover glass in sea water, lateral view.

10. The same, vertical view.

11. Another lateral view of epidermal cells with basement membrane.

12. Epidermal cells showing degenerative changes. These changes took place rapidly under pressure. 


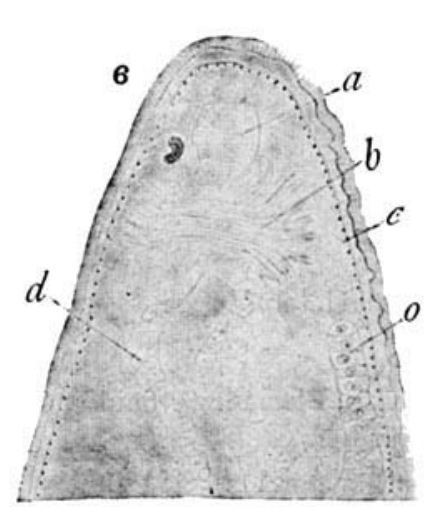

11
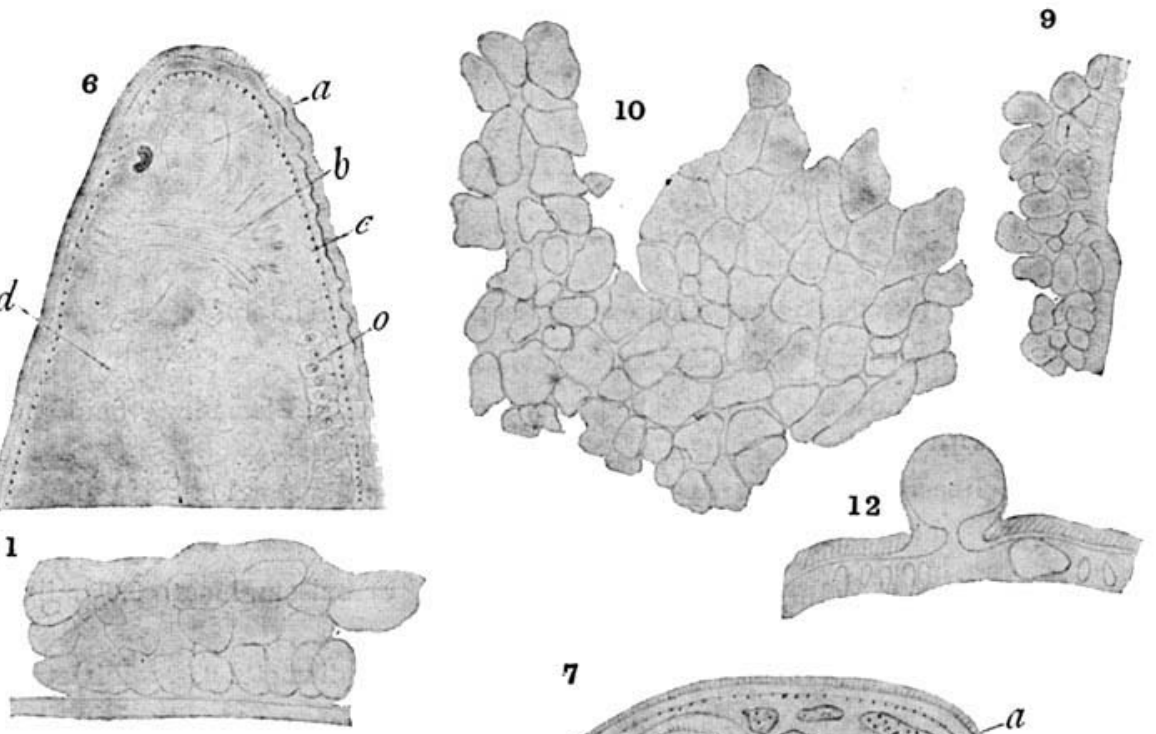

8
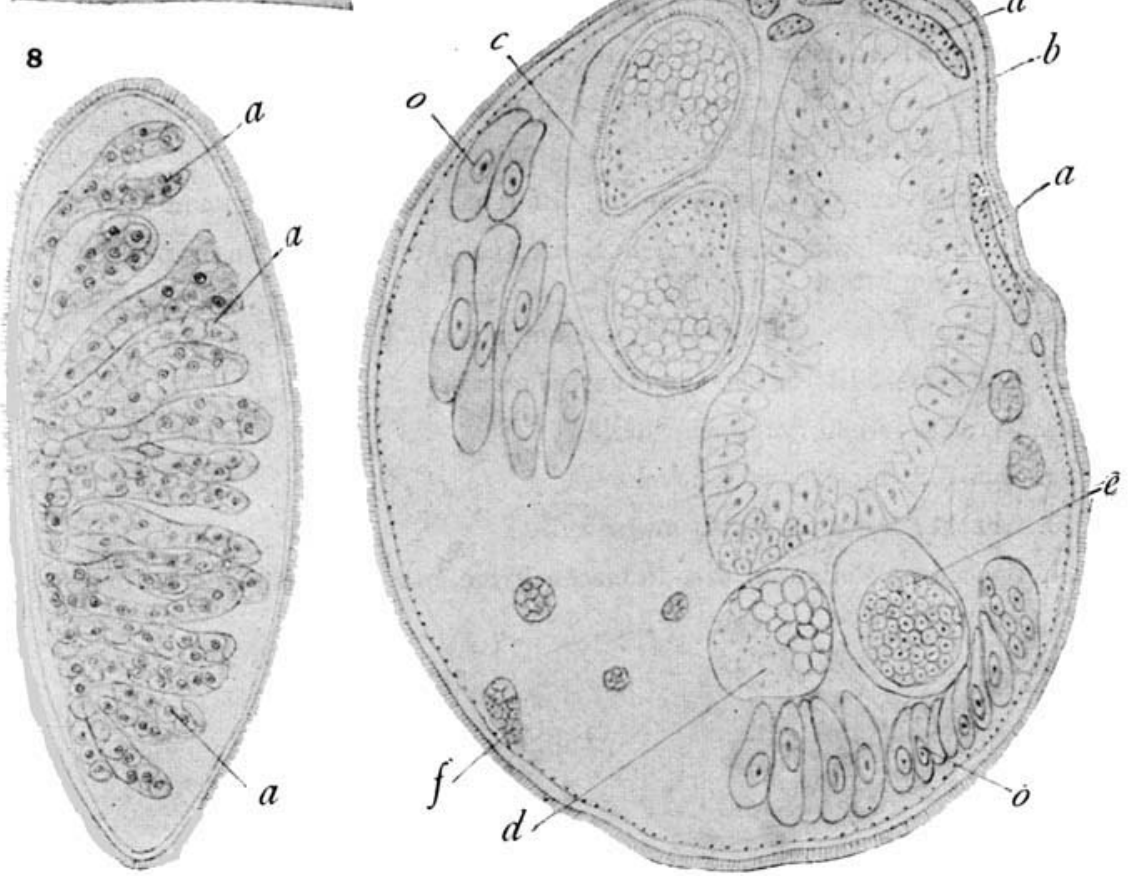

THE JOURAAL OF EXPFRMENTAL zoÖLOGY, Vol, 9, No. 2 . 


\section{PLATE 3}

\section{EXPLANATION OF FIGURES}

13. Nerve plexus, sketch from life of region posterior and lateral to eye.

14. Ganglion-like part of plexus much enlarged.

15. Plan of muscle fibers, sketched from section fixed in Flemming's fluid and stained with iron hematoxylin.

16. Collapsed embryonic capsule, life; length 0.07 millimeter.

17. Two of the same, from specimen mounted in balsam, length; 0.07 millimeter.

18. Another of the same from specimen mounted in balsam, length 0.05 millimeter.

19. Ovum from specimen mounted in balsam, longest diameter 0.09 millimeter.

20. Ovum with several cells in fine-granular yolk, same magnification as fig. 19 .

21. Ovum with cluster of cells in midst of granular yolk.

22. Orum with two clusters of cells at opposite poles separated by yolk.

23. Two ova, each with two embryos already formed in the midst of the yolk.

24. Three ova in place, representing different stages of development, from life.

25. Ovum containing only large nucleated cells, all the yolk has been absorbed; not a usual condition.

26. Twins in embryonic capsule, diameter about 0.04 millimeter.

27. The same, a little older than those shown in fig. 26.

28. Triplets in embryonic capsule.

29. Twins in capsule, eyes developert.

30. Another pair more highly magnified.

31. Sperm-sac, collapsed, free in mesenchyme, probably distorted by pressure. 

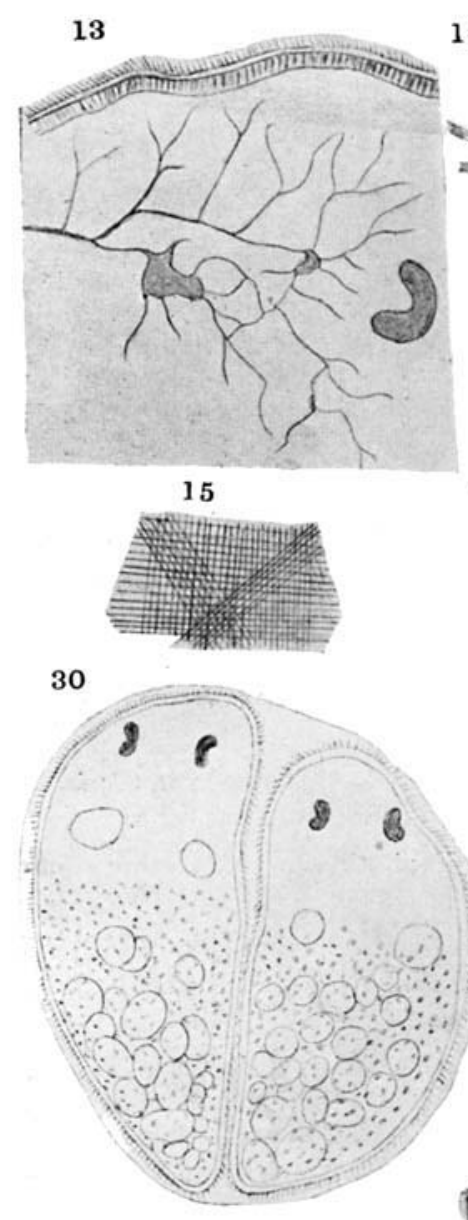

19

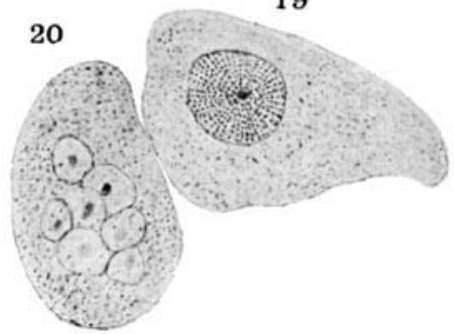

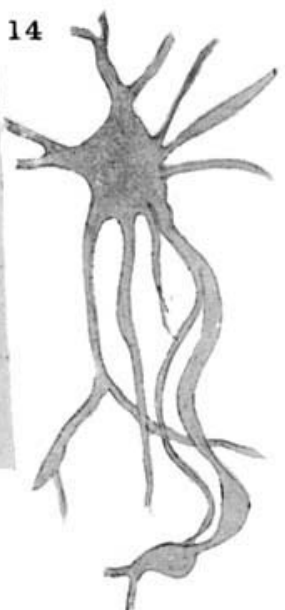

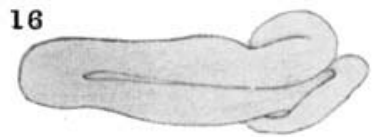

18
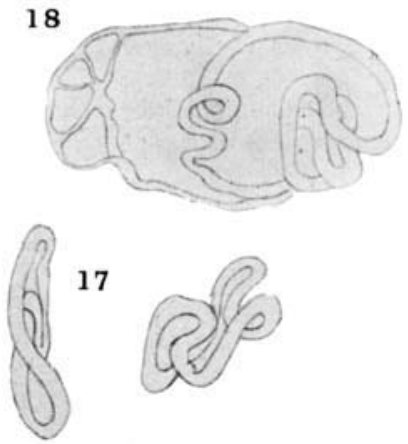

17

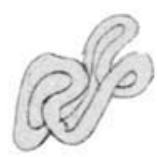

21

29
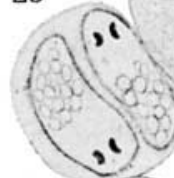

26

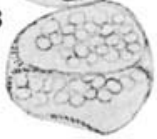

31

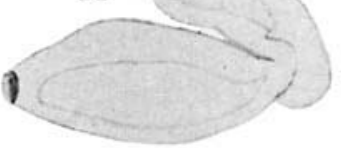

25

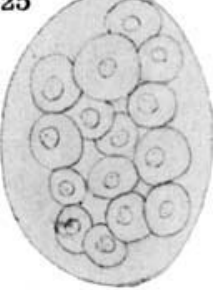

23

24

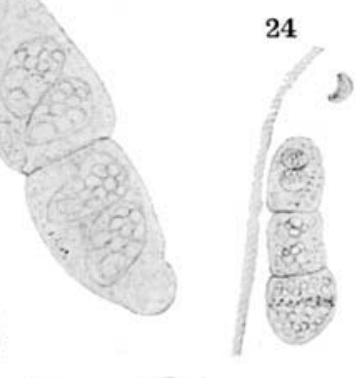

28

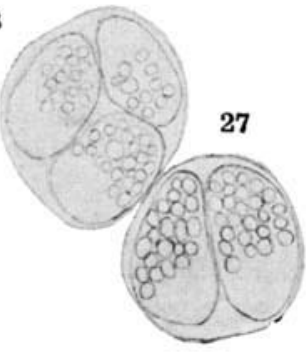

THE JOURNAL, OF FXPERIMENTAL, ZOÖLOGY, VOI. 9, NO. 2 


\section{PLATE 4}

\section{EXPLANATION OF FIGURES}

32. Tangential section through sperm-sac and a little to one side of the genital pore. $a$, uterus; $b$, sperm-sac; actual diameter of sac 0.05 millimeter.

33. Horizontal section. $a$, genital pore; $b$, uterus.

34. Horizontal section. $a$, penis; $b$, uterus; one section intervenes between 33 and 34 .

35. Next section to 34 . $a$, penis; $b$, uterus.

36. Next section to 35 . $a$, sperm sac; $b$, uterus. Figs. 33-36 are drawn to the same scale; the diameter of the sperm sac in 36 is 0.05 millimeter. The sections were at least .005 millimeter thick.

37. Sperm sac, $a$, and ovum engaged in what appeared to be a kind of copulatory action; free hand sketch from life; $e$, wisp of spermatozoa (see p. 376 for description).

38. A somewhat similar condition is here indicated to that shown in 37; from specimen mounted in balsam. $a$, sperm-sac; $b$, ovum with two germ cells.

39. Empty sperm sac and ovum sketched from life; both were contracting somewhat rhythmically. $a$, sperm-sac; $b$, ovum.

40. Horizontal section showing the ovary-vitellarium. a, cells of ovary with the characteristically large germinal spots; $b$, yolk-forming cells; $c$, uterus; $d$, spermatozoa in duct; diameter of section 0.3 millimeter.

41. Another horizontal section, the fifth dorsal to the one shown in fig. 40. $a$, ovary; $b$, ovum with one cluster of cells showing in the section. A study of the succeeding sections shows that the ovum has another cluster of cells and is of the type shown in fig. 22. c , a nearly transverse section of a young worm. The section passes a little diagonally through the posterior end. Adjacent sections show that this is one of a pair of twins lying in their capsule. $d$, ciliated young with eye-spots. This specimen had escaped from its capsule. $e$, yolk-forming cells of the ovary-vitellarium; $f$, notch showing the continuation of the duct $c$ in fig. 40 , and continuous with the uterus of figs. 33-36. The positions of $b$ and $d$ were changed slightly to bring them within a smaller compass; breadth of section 0.3 millimeter. 


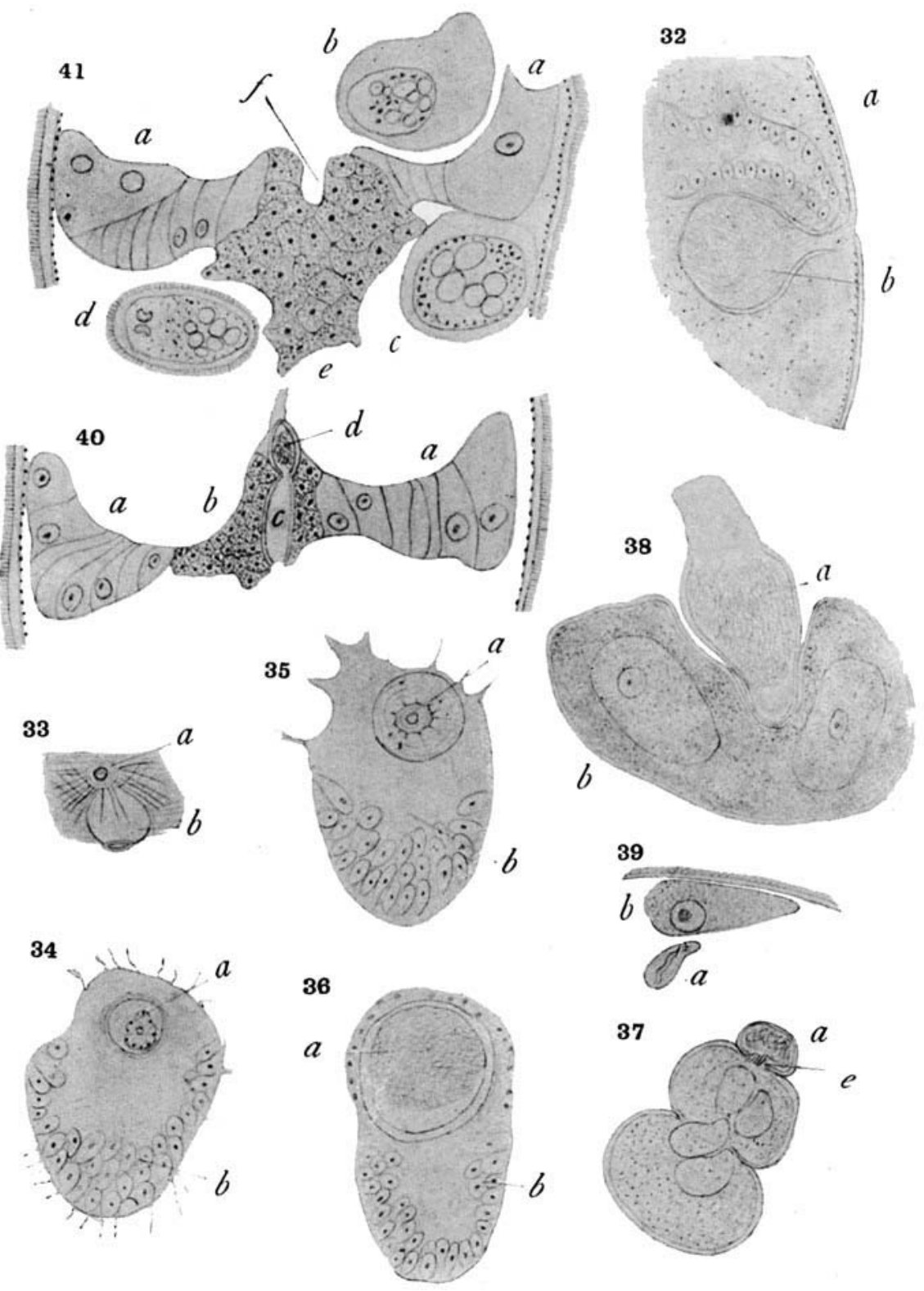

THE JOURNAL OF BXPERIMENTAL ZOBLOGT, YOL, 9, No. 2. 